\title{
12. Vanuatu Nasonal Film Unit
}

\author{
Jacob Kapere
}

Gud aftenun long yumi evriwan mi gat bigfala hona blong stanap long fes blong yufala ol hae woman, man we oli harem nem blong yufala bifo mo yufala i mekem plante wok long Vanuatu mo i gud tu blong luk yufala evriwan yufala i kam joen olsem wan famle blong ol riseja we oli joenem grup blong ol filwoka mo ol man blong Vanuatu film unit. Mi mi bin joenem film unit long 1986 taem Kirk hemi faenem mi long rod long taon ating hemi bin faenem mi long nakamal hemi faenem se mi mi bin gat smol skil long saed blong video kamera. Nasonal Film Foto mo Saon Unit hemi olsem wan nasonal dipositri blong plante samting long saed blong film, foto mo saon mo hemi olsem wan kastom bang hemi olsem wan ples we i stap long hat blong miusium long ples ia we yumi stap risejem ol kastom save blong kantri ia long hem. Ples ia hemi olsem hat blong hemi stap yet be ol branj ol aktiviti blong hem i stap olbaot long ol aelan we hemi minim se stamba wok blong olgeta nao ol man oli bin setemap ples ia nao hemi olsem ol filwoka ol fes riseja we oli bin stap long kantri. Taem yu tokbaot film unit olsem plante taem ol man oli harem long saed blong filming o rikoding be long bifo mi gat plante man blong yumi oli bin fraet lelebet long taem bifo from ating oli luk ol fes riseja we oli bin go long sam aelan blong yumi oli bin rikodem ol man oli plem oli harem voes blong olgeta an oli go oli nomo kambak plante oli nomo kambak oli bin stap long taem. Afta oli ating, putum wan nem we hemi olsem se ol masin we oli yusum hemi ol masin we oli stilim voes mo oli stilim man oli minim se olsem olgeta oli no save tumas se. Mo oli no bin save se i bin gat wan seksen olsem we i stap long Kaljorol Senta we oli save ron i kam olsem naoia. Oli ron i kam blong faenem plante samting an bifo ino bin gat, mekem se wok we oli bin mekem long kantri spirit i bin stap long hem oli tekem yet oli stap olsem se hemi propeti blong Vanuatu. Wan dei hemi mas kambak long Vanuatu an mekem se taem olgeta we oli bin setemap seksen ia oli bin traehad blong karem ol samting ia tu i kambak.

So wan long olgeta fes man we mi mi bin joenem wok blong olgeta long taem lelebet mi olsem kolosap nomo be mi stap kam olfala. Mi no stap luksave be taem mi luk ol olfala filwoka mi save ol man we oli stap long ples ia olsem fes filwoka we yumi bin harem nius blong olgeta long moning James Gwero we hemi stap mo Richard Leona olgeta nao oli bin stap blong bildimap bang blong save ia blong kastom so James Gwero hemi wan long olgeta fes man we hemi stap rikodem ol samting mo hemi bin aot blong trenem olgeta blong hao blong oli yusum ol kaen ekwipmen olsem ia blong rikodem ol samting. An James ino long taem tumas hemi stap ia hemi kam long hem be hemi talem se, bifo solda 
blong hemi bin so lelebet from ol ekwipmen blong bifo i bin hevi. Hemi talem long mi se, 'Man yufala naoia yufala ino stap wok had tumas ia mifala bifo mifala swet gud ia!' We ating hemi kam hemi luk se i gat plante man an ino gat inaf blong yumi go aot long aelan blong rikodem.

Be hem wetem ol narafala koligs blong hem blong oli stat mekem wok from tingting ia nao olsem ol man ples i talem se sam waet man oli bin kam stilim voes blong mifala finis, oli kam stilim mifala oli kam stilim foto blong mifala bakegen ale yufala bakegen yufala i kam blong wantem mekem ol wok ia. So mekem se wetem help blong Kirk Huffman hemi bin traehad mi sua se sam long yufala ol riseja we oli stap naoia ol olfala riseja i bin helpem hem blong aedentifaem sam samting olsem ol foto we yufala we oli wok long defren institiusen ovasis i bin save sam foto wetem sam audio wetem sam film we oli bin karem long bifo. An wan long olgeta bigfala wok we oli bin traehad blong karem ol samting i kambak hemi olsem wok blong risej ia nao we Kirk hemi bin faenem long ovasis an hemi manej blong karem fes film blong yumi long 11 minit long vilej blong Matantua long 1917 we man ia hemi bin kambak bakegen 1919 blong mekem ol film blong Vao, Malakula mo sam nara ples bakegen hemi bin mekem longfala film.

Be long risej long Kirk hemi faenem aot se bigfala pat blong film ia hemi bin lus, oli bin distroem so yumi laki tumas blong gat 11 minit ia we hemi pat blong Solomon tu i stap insaed long hem. Mo ol fes foto we oli bin stap tu long taem ia olsem long ripot blong Tepahae i stap givim naoia se 1852 sam samting long Aneityum hemi no longtaem. Wan yia afta hemi 1853 hemi ol fes foto we Kirk hemi bin karem blong kambak long Kaljoral Senta. Fes koleksen ia nao we i olfala i blak an waet we i kam i stat blong bildimap kastom bang blong yumi. Sem taem hemi stat blong leftemap intres blong pipol taem we oli stat blong karem i go bak long aelan blong soem long ol pipol bakegen mo ol fes rikoding.

I gud blong yumi traem karem ol samting ia i kambak ovasis fastaem so long tabu rum i gat plante plante blak an waet foto we oli bin kolektem long plante defren miusiums wetem yunivesitis. Mo plante long ol foto ia mifala i stil stap traehad blong faenem ol infomesen blong olgeta yet blong go wetem so ol foto oli stap wetem ol rikodings. Ol rikodings long taem ia oli bin stap long defren fomat mekem isies wei we long taem we Kirk olgeta oli bin stap manij blong holem taet ol sikistin o ol rikoding olsem ol riliz ol fes film oli stap long sikistin milimita film olsem sinema be oli bin transferem olgeta oli go long VHS. Nao stamba wok blong ol filwoka mo ol man ples hemi blong go aot blong kolektem ol infomesen. Ol infomesen long aelan, rikodem ol samting, filming ol samting blong kam putum long fiuja jeneresen from oli luksave se lanwis i stap jenis folem laef we yumi stap go long hem. Ol man oli stat muv i kam long taon plante oli luksave se lanwis bambae hemi jenis mo lanwis hemi stamba blong plante samting we oli stap mekem long aelan. Olsem long lanwis nao hemi mekem se i 
gat wan kastom i kamaot long wan eria oli pefom long wan wei from we lanwis nao hemi talem oli save se sipos ino gat lanwis bae kastom ia ino save gat wan mining we mufmen blong tanis o ol samting we i go insaed long tanis bae ino gat. So hemi mekem se film unit hemi gat stamba wok blong oli traem blong kolektem plante infomesen bifo ol samting oli stat blong lus. Taem we mi mi stat mi bin foldaon long sem spirit we mi blong go aot nomo blong karem o filming ol samting blong karem bak blong putum long akaef an plante plante long olgeta oli talem se olsem ol samting we oli rikodem ol samting we yumi rikodem blong kasem we oli blong fiuja jeneresen. Yumi traem blong putum i go long narafala institiusen bakegen blong hemi yusum so hemi olsem ol samting blong olgeta we i stap we oli save se wan dei oli ded be ol pikinini blong olgeta oli go long ples ia bae oli save faenem plante samting we oli save divaedem sam samting bakegen.

James Gwero hemi stap blong yusum smol muvi kamera we hemi 8 milimita film hemi wan smol muvi film we i bin gat sam we oli bin transferem be plante oli no transferem yet i stap. Nekis fomat we i bin kamaot long taem ia long maket hemi Video 8 an Video 8 Viane hemi bin yusum, Viane hemi olsem wan filwoka hem tu i bin yusum mo Alben Ruben, hem blong South West Bay we Kirk hemi bin spendem plante taem long eria ia blong mekem ol stadi blong hem an hemi faenem se ples ia hemi nidim wan kamera so hemi bin askem James Gwero i kam karem smol trening. Alben oli sendem hem i go long Fiji i karem smol trening bakegen i kambak saye oli karem wan video kamera mo bifo oli sendem video kamera wetem hem blong go long aelan hemi sendem toktok i go long aelan se bae kasem aelan wetem wan video kamera. Be ol man aelan oli no save gud tumas mo oli no bin luk pija blong olgeta bifo. Samfala oli harem oli spretemaot nius mekem se ol jifs oli bin oganaesem wan bigfala seremoni long dei blong ol jifs long namba 5 maj we oli stap selebretem oltaem mo oli bin gat wan seremoni oli bin blesem Alben wetem video kamera blong hem bifo hemi stat blong yusum long fil so hem tu hemi gat wan koleksen. Bigfala koleksen i stap mo long taem ia nao we mi mi kam blong go joenem olgeta an ten mifala yusum video 8 , mifala yusum hai 8 we hemi nekis fomat i aot long afta long video 8. Mo mifala yusum ol defren fomat we yu save faenem ol kaset blong hem oli stap long tabu rum hemi i gat 16 milimita, i gat 8 milimita, i gat video 8 , i gat hai 8 , i gat VHS, i gat SVHS, i gat DV, i gat DVC Broadcast. Evri koleksen we mifala i gat most long olgeta oli transferem olgeta long VHS an ten mifala i traehad blong transferem olgeta bakegen yu putum i go long fomat we hemi DVC Broadcast mo olsem mi talem i gat plante we oli no transferem olgeta yet naoia.

Olsem i kam long wan taem we yumi stat blong luk save se tabu rum hemi olsem wan kastom bang. Be kastom bang ia hemi gat hemi olsem mani we i gat intres blong hem an intres blong yu mas benefitim komiuniti so yumi mas yusum. Mekem se long 1990 samting mifala i stat blong mekem ol fes program blong 
mifala long kastom mo kalja long TV kasem naoia. Naoia mifala stap kontiniu yet blong mekem an oli givim taem long mifala blong mifala i stap yusum tu haoa long wan wik i mekem se i gat tu taem long wan manis we mifala i save yusum koleksen blong mifala o go aot blong filmim wanem blong kam blong mekem program blong hem blong putum long TV sendem kopi long aelan blong ol man oli save luk.

So naoia olsem ol man oli wantem, yumi wantem mekem se ol man oli get yus long ol samting we yumi gat blong promotem kastom blong promotem lanwis blong karem bak intres blong bringim intres blong pipol i kam antap. Mo long saed blong radio mifala i stap gat ol kastom mo kalja radio program long evri Satede blong afanaoa hemi stap kamaot long af pas sikis i go long seven klok. Mifala i bin raetem blong ekstendem taem tu blong oli pasem ol program blong Paul Gardissat we hemi bin stap long radio long taem blong New Hebrides i kam long Vanuatu mo hemi bin stap mekem ol program long saed blong kastom. Program ia tu mifala i stat blong mifala i iven toktok long olgeta long radio oli glad blong putum so i minim se mifala i traem blong winim mo taem long radio blong pasem ol samting blong yumi i go long hem.

Ol foto blong yumi mifala i stap i gat wan kolum long Daily Post niuspepa we evri wiken i stap go long hem mo mifala i traehad blong mekem se i traem kamaot tu long evri dei so mifala i yusum ol foto ol olfala foto ol blak an waet foto blong putum i go. I gat ol pablikesen tu we i stap kamaot we oli yusum ol storian we oli bin rikodem we i stap long tabu rum blong mekem ol buklet blong kastom stori mo hemia we oli kolektem so hemia tu olsem hemi pat blong wok blong yumi traem blong mekem se pipol i yusum wanem we yumi gat.

Mifala i gat wan nasnal polisi blong filming tu we i stap we mifala i stap moniterem ol defren film kru we oli stap kam long ples ia hemi minim se spos wan film kru i wantem mekem wan film long saed blong kalja long Vanuatu hemi mas aplae i kam blong mifala i in advans an hemi no wan bigfala kampani nomo be i save kam olsem wan wan man so i gat plante i respektem samting ia be plante ino respektem an mifala i save se i gat plante long ol wok ia tu oli stap long ovasis yet. Evri taem we oli kam i mas gat wan ofisa blong kaljorol senta i mas folem olgeta i go long aelan blong kontrolem olgeta blong mek sua an sapos we oli save se olsem polisi i stap nao. Mi wantem putum long ol riseja we oli bin mekem wok bifo se sapos sam long yufala ino bin givim wok long yufala yet olsem ol rikoding ol foto i save kam putum olsem tabu rum i gat ol rul blong hem hemi stap long Kaljoral Senta hemi blong fiuja jeneresen mo mifala i gat databes blong hem mo ol foto i gat databes blong hem blong putum ol infomesen blong mekem se ol man oli save kam blong yusum ol samting ia tu isi. Tangkiu tumas. 


\title{
The Vanuatu National Film Unit
}

\author{
Jacob Kapere
}

Good afternoon everyone, I have great honour to stand in front of all of you important women and men whose names I have heard before, who have done lots of work in Vanuatu, and it is good to see you all coming together like a family of researchers joining with the fieldworkers and the staff of the Vanautu Film Unit. I joined the film unit in 1986 when Kirk found me on the street in town, maybe it was in a nakamal, and he saw that I had some skills in using a video camera. The National Film Photo and Sound Unit is a national repository for anything on film, or photos or audio recording and it is also a kastom bank, like the heart of the museum here where we can research kastom knowledge from Vanuatu. This place is like a heart in that it branches into different activities on all the islands, and the main work is done by the fieldworkers and the first researchers who worked in the country. When you talk about the film unit now everyone knows about filming and recording, but before there were many ni-Vanuatu who didn't trust filmmakers because of their experience before with the first researchers who came in and recorded people, they played the recording and they heard the voices, but they never came back. Then the old people called these machines 'voice-stealers' and they thought that they stole the people too, because they didn't know too much about such things. And they didn't know that there was a special section at the Cultural Centre which keeps all these recordings. They can come and find lots of recordings made in the past, the spirit of the country is there; it is kept as the property of Vanuatu. One day it must come back to Vanuatu and so all those who set up the National Film and Sound Archive have been trying hard to bring back all of these recordings.

I was one of the first ones to join this section and now I am becoming an old man. It doesn't seem like that to me, but when I look at the older fieldworkers, I can see that the ones who were here as the first fieldworkers, who we heard from this morning, James Gwero and Richard Leona, they are the ones who built up the knowledge bank about kastom. James Gwero is one of the first to have recorded all this and he went out to train others in using the equipment to record all these things. As he told us, his shoulders were sore because the equipment in those days was heavy. He said to me, 'Today you don't work so hard, not like us before, we used to sweat hard!' He can see that while there are plenty of fieldworkers there are still not enough for us to go to the islands to record.

But James, together with his colleagues, started this work because people were saying the white men had come and stolen their voices, they stole their 
photos, and now you have come to do the same thing. So, with the help of Kirk Huffman, James and I'm sure others of you researchers who are here helped to identify these things, like photos, that you who work in overseas institutions knew about, also films and audio recordings. It was a lot of work to get this material copied and sent back to Vanuatu. Kirk managed to find the first film made in Vanuatu, an 11-minute film from Matantua village in 1917, and the filmmaker came back in 1919 to make a longer film about Vao in Malakula and some other places.

But Kirk also found out that most of the film had been lost, so we are lucky to have eleven minutes with some footage from the Solomons in it too. And we also found the first photos, as Philip Tepahae's report noted; they are from somewhere around 1853 from Aneityum. This first collection in black and white started building up our kastom bank. At the same time it began to build up people's interest as they started to take these things back to their islands.

We have tried to bring these things back from overseas and in the tabu room there are lots of black and white photos collected from many different museums and universities. We are still searching for information about the photos we have so they can go together with recordings. The films in those days were in a different format, usually sixteen millimetre, but they were transferred to VHS. Now the main job for fieldworkers and other ni-Vanuatu is to collect information. Information from the islands, record everything, film everything and preserve it for future generations so that they can understand that language changes with the new life we are moving into. Many people are moving into town and they recognise that their language is changing and that language is the basis for lots of cultural activity on the islands. So in the language there is a way of performing a kastom ceremony in a particular area because the language tells them. If there was no language then the kastom would have no meaning, like a dance movement or other parts of a dance would have no meaning.

So that is why the film unit's basic work is to collect lots of information before it is lost. When I started I also went out and filmed and put the films in the archive and many people say that the things we recorded are for the future generations. We also put copies in other institutions so they can be used, so that it reflects the people who are there today who know that they will be gone, but their children will be able to go to this archive and find these things again.

James Gwero used a small 8 millimetre camera and some of his films have been transferred to VHS, but many have not yet been transferred. The next format to come out was Video 8 and Viane used Video 8. Viane was a fieldworker, and so did Alben Reuben, from South West Bay, a place where Kirk spent a lot of time doing his research and he thought the area needed a camera so he asked James Gwero to do some training. They sent Alben to Fiji to do some training then they had a small video camera and before he went to an island they sent a message 
saying they would come with a video camera. People on the islands didn't really understand and they hadn't seen pictures of themselves. Some of them spread the news and the chiefs organised a ceremony on Chiefs' Day, March 5, and they blessed Alben with his video camera before he started using it. There is a big collection of films and then, when I came, we used Video 8 and High 8 which was the next format. We used all the different formats which you can still find in the tabu room, there is 16 millimetre, 8 millimetre, Video 8, High 8, VHS, SVHS, DV, DVC Broadcast. Most of the collections were transferred to VHS, then we transferred to DVC Broadcast, but there are many that aren't transferred yet.

So now we come to a time where we look at the tabu room as a kastom bank. But it is a bank where the money has interest and the interest has to benefit the community, so we all have to use it. In 1990 we started to put programs about kastom and culture on television. Now we are still making these programs and they give us a timeslot of two hours per week so twice a month we can use our collection or go out and film something to put on television and send copies to the islands.

So now we want everyone to get used to the collection to help promote kastom, language, to raise people's interest. And on the radio we have a kastom and culture program every Saturday for half an hour from 6.30 to 7.00 p.m. We asked them to extend this time to replay all the programs that Paul Gardissat made long ago in the time of the New Hebrides, about kastom. We talked to the radio people and they were happy to put these programs on again.

Our photos are in the Daily Post every weekend and we could even put one in every day to use all the photos in the collection. There are publications that have come out which use stories that were recorded and are in the tabu room, booklets with kastom stories, so that is also part of our work to get people to use the material that we have.

We have a national film policy so we monitor all film crews so, if a film crew wants to make a film about culture in Vanuatu they must apply to us in advancenot just big companies, even just some one who wants to film-lots of people respect this, but lots also don't respect this policy so we know there is lots of film overseas. Every time a film crew comes it must take an officer from the Vanuatu Kaljoral Senta (VKS) with them to the islands to control what they do and to make sure they understand the policy.

So I want to ask all researchers to deposit their work, like photos or recordings, in the tabu room and there are rules at the Cultural Centre so they will be there for future generations. There is a database of all of this and there are photos in the database so it is easy to find information there.

Thank you very much. 